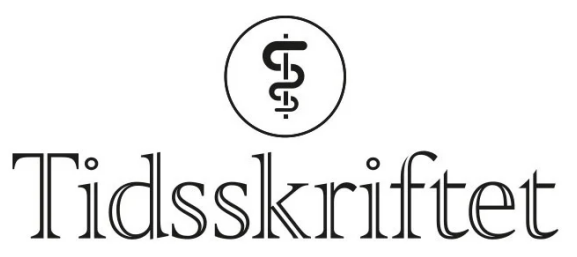

DEN NORSKE LEGEFORENING

\title{
Pasientsentrert behandling - er det mulig?
}

LEDER

\section{NINA AASS}

Nina Aass er seksjonsleder for Seksjon for lindrende behandling, Avdeling for kreftbehandling, Oslo universitetssykehus og professor ved Institutt for klinisk medisin, Universitetet i Oslo. Forfatteren har fylt ut ICMJE-skjemaet og oppgir ingen interessekonflikter.

\section{STEIN KAASA}

stein.kaasa@medisin.uio.no

Stein Kaasa er avdelingsleder for Avdeling for kreftbehandling, Oslo universitetssykehus og professor ved Institutt for klinisk medisin, Universitetet i Oslo.

Forfatteren har fylt ut ICMJE-skjemaet og oppgir ingen interessekonflikter.

\section{Det kreves mer enn gode resultater fra kliniske studier for å få til pasientsentrert behandling.}

«Kartlegging og behandling av munnhuleproblemer er noe vi dessverre ikke gjør rutinemessig. Vi burde gjort det - men det er så mye annet viktig vi må rekke i en travel hverdag på en sengepost for kreftpasienter.» Denne samtalen mellom sykepleier og lege overhørte vi nylig. Den er sannsynligvis beskrivende for prioriteringer flere steder i norsk spesialisthelsetjeneste. En norsk studie har dokumentert at det ikke er særlig bedre ved norske sykehjem (1). Munntørrhet er en subjektiv tilstand, i likhet med smerte, angst, tretthet og kvalme og kan måles ved å spørre pasientene. Munntørrhet kan være svært plagsomt, men kan forebygges og behandles, slik den kliniske oversikten Kvalheim og medarbeidere nå publiserer i Tidsskriftet, viser (므).

Symptomer må systematisk kartlegges. Dette er en viktig del av anamneseopptaket, enten pasienten kommer til konsultasjon hos fastlegen, på sykehusets poliklinikk eller tilses på sykehus eller i sykehjem. Ved behandling av symptomer må pasientene også følges opp med en plan for å vurdere behandlingseffekt, slik at man raskt kan justere behandlingen. Dette er viktig for alle pasienter, men spesielt viktig for pasienter med kort forventet levetid.

En mulig forklaring på at subjektive symptomer ikke blir systematisk kartlagt og behandlet i norsk helsevesen, er at man mener at man allerede gjør det godt nok i rutinepraksisen. Mye tyder på at det ikke er tilfellet. I flere gode randomiserte studier er det vist at 
plagsomme symptomer og generell livskvalitet blir betydelig forbedret hvis man systematisk kartlegger symptomene, igangsetter behandling, evaluerer denne og om nødvendig følger opp med ytterligere kartlegging.

Vel 750 pasienter med solide svulster og metastatisk sykdom ble inkludert i en randomisert studie på en kreftpoliklinikk i USA (3). Alle pasientene fikk standard tumorrettet behandling og ble randomisert til enten rutinemessig oppfølging eller systematisk kartlegging av de 12 vanligste symptomene hos pasienter som får medikamentell kreftbehandling. Pasientene i intervensjonsarmen rapporterte symptomer regelmessig på et nettbrett. Ved symptomintensitet over et visst nivå ble sykepleier på poliklinikken varslet digitalt. Legen fikk utskrift av symptomene, og adekvat behandling ble igangsatt. Signifikant flere av disse pasientene rapporterte bedret livskvalitet etter seks måneder enn pasientene som fikk standard oppfølging. I tillegg levde pasientene i intervensjonsgruppen i median fem måneder lenger, færre av dem hadde akuttinnleggelser på sykehus, og intensivbruken var lavere. Vi antar at denne og flere tilsvarende studier er overførbare til norske forhold både innen kreftomsorgen og øvrig somatikk. Slik dokumentasjon har vært kjent i mange år, og det finnes klare nasjonale anbefalinger om systematisk å kartlegge symptomer (4). Dessverre er det lite som tyder på at klinisk praksis er endret i norske sykehus og sykehjem.

\section{«Den systematiske kartleggingen av symptomer og funksjoner er skjøvet nedover på prioriteringslisten»}

I de siste tiårene har flere nye bildediagnostiske metoder og bedret molekylær biologisk diagnostikk medført at man kan tilby mange pasienter persontilpasset behandling. Store investeringer er gjort i forskning og ny teknologi innen somatisk medisin. Det etablerte det gamle, nemlig den systematiske kartleggingen av symptomer og funksjoner, er skjøvet nedover på prioriteringslisten. Det gamle blir fort glemt og utelatt når det kommer mye nytt. Det er mulig å forstå at dette skjer, men det går ut over totaltilbudet om persontilpasset behandling, som omfatter langt mer enn fokus på biologiske parametere. Etter vårt syn må det både en holdningsendring og en systemendring til, både når det gjelder utdanning av leger og prioriteringer som gjøres av politikere og helsebyråkrater, av ledere i helsevesenet og av den enkelte lege.

Det er et stort fokus på å behandle pasientens sykdom i dagens helsevesen, mens behandling av pasienten med sykdommen vies mindre oppmerksomhet. Det siste er det som omtales som pasientsentrert behandling. Flere gode kliniske studier har vist at en organisering og gjennomføring av pasientbehandlingen som ivaretar både sykdommen og pasienten med sykdommen, gjør at pasientene med uhelbredelig sykdom kan være mer hjemme, at de har bedre livskvalitet, færre plagsomme symptomer og lever lenger $(5, \underline{6})$. For at en slik tilnærming skal bli en del av rutinebehandlingen, har et bredt internasjonalt panel anbefalt å utvikle og implementere pasienttilpassede forløp (7.). Disse anbefalingene inngår også i en norsk offentlig utredning fra 2017 (4).

Det er ikke vanskelig å være enig i at godt munnstell hos alvorlig syke pasienter bør være et minimum av hva dagens norske helsevesen skal tilby. Dessverre er dette neppe tilfelle i dag. Fortsatt erfarer mange pasienter med kort forventet levetid og deres pårørende at noe «så enkelt» som grunnleggende munnstell ikke blir utført.

\section{LITTERATUR}

1. Kvalheim SF, Strand GV, Husebø BS et al. End-of-life palliative oral care in Norwegian health institutions. An exploratory study. Gerodontology 2016;33: 522-9. [PubMed][CrossRef]

2. Kvalheim SF, Marthinussen IMC, Berg E et al. Munntørrhet hos alvorlig syke og døende. Tidsskr Nor Legeforen 2022;142. doi: 10.4045/tidsskr.21.0232. [CrossRef] 
3. Basch E, Deal AM, Kris MG et al. Symptom Monitoring With Patient-Reported Outcomes During Routine Cancer Treatment: A Randomized Controlled Trial. J Clin Oncol 2016;34: 557-65. [PubMed] [CrossRef]

4. NOU 2017: 16. På liv og død - palliasjon til alvorlig syke og døende. https://www.regjeringen.no/no/dokumenter/nou-2017-16/id2582548/ Lest 25.1.2022.

5. Jordhøy MS, Fayers P, Saltnes T et al. A palliative-care intervention and death at home: a cluster randomised trial. Lancet 2000; 356: 888-93. [PubMed][CrossRef]

6. Temel JS, Greer JA, Muzikansky A et al. Early palliative care for patients with metastatic non-smallcell lung cancer. N Engl J Med 2010; 363: 733-42. [PubMed][CrossRef]

7. Kaasa S, Loge JH, Aapro M et al. Integration of oncology and palliative care: a Lancet Oncology Commission. Lancet Oncol 2018; 19: e588-653. [PubMed][CrossRef]

Publisert: 14. februar 2022. Tidsskr Nor Legeforen. DOI: 10.4045/tidsskr.22.0072

(C) Tidsskrift for Den norske legeforening 2023. Lastet ned fra tidsskriftet.no 26. april 2023. 